\title{
APLIKASI ANALISIS KLASTER DAN INDEKS TRIX UNTUK MENGKAJI VARIABILITAS STATUS TROFIK DI TELUK PEGAMETAN, SINGARAJA, BALI
}

\author{
Turmuzi Tammi"*\#, Niken T.M. Pratiwi"), Sigid Hariyadi"), dan I Nyoman Radiarta") \\ ") Departemen Manajemen Sumber Daya Perairan, Fakultas Perikanan dan Ilmu Kelautan, Institut Pertanian Bogor \\ ") Pusat Penelitian dan Pengembangan Perikanan Budidaya
}

(Naskah diterima: 9 Maret 2015; Revisi final: 3 Juni 2015, Disetujui publikasi: 5 Juni 2015)

\begin{abstract}
ABSTRAK
Tren variabilitas status trofik adalah informasi dasar pengelolaan ekosistem perairan dalam kaitannya dengan tingkat eutrofikasi. Tujuan penelitian ini adalah menentukan tren variabilitas status trofik baik secara spasial dan temporal sehingga dapat diterapkan dalam konsep pengelolaan perairan. Selama tiga bulan penelitian (Agustus-Oktober 2014), penelitian ini telah berhasil mengumpulkan data dari 48 titik pengamatan baik saat pasang maupun surut yang bertepatan saat bulan purnama maupun gelap. Data yang dikumpulkan lalu dianalisis secara statistik (analisis klaster) dan penentuan indeks TRIX. Hasil analisis secara spasial menunjukkan bahwa lokasi penelitian terbagi menjadi dua wilayah yakni: K1 untuk kawasan

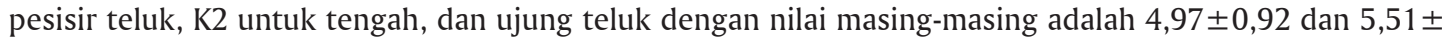
0,90. Analisis secara temporal menghasilkan dua kelompok yakni pada bulan Agustus (A1) dan SeptemberOktober (A2) dengan nilai indeks TRIX masing-masing 4,28 $\pm 0,99$ dan 5,78 $\pm 0,27$. Berdasarkan analisis klaster dan indeks TRIX telah menunjukkan secara jelas bahwa kondisi kawasan klaster K1 lebih baik dibandingkan kawasan klaster K2. Kawasan K1 masih dapat dikembangkan untuk budidaya laut keramba jaring apung (KJA), namun dalam perkembangannya, budidaya laut secara terintegrasi berbasis integrated multi-trophic aquaculture (IMTA) dapat diterapkan guna menjaga daya dukung lingkungan perairan Teluk Pegametan. Tren secara temporal menunjukkan pola yang mengikuti fluktuasi air atau pasang surut, serta jadwal kematian massal ikan setiap tahunnya dan berbeda nyata pada saat Agustus hingga SeptemberOktober. Hasil penelitian ini diharapkan memberikan informasi tentang kondisi perairan Teluk Pegametan sehingga dapat dilakukan pengelolaan kawasan yang lebih baik untuk kegiatan budidaya laut yang berkelanjutan.
\end{abstract}

KATA KUNCI: variabilitas, analisis klaster, indeks TRIX, status trofik, IMTA, Teluk Pegametan

ABSTRACT: Application of analysis cluster and TRIX index to assess variability trophic state in Pegametan Bay, Singaraja, Bali. By: Turmuzi Tammi, Niken T.M. Pratiwi, Sigid Hariyadi, and I Nyoman Radiarta

Trend variability of trophic state is the basic information in order to manage ecosystem aquaticin relation with status of eutrophication. The objective of this study was to determine the trend variability of trophic state index in spatial and temporal variations that could be used as a concept in aquatic resources management. In three months observation (August-October 2014), this study has been succesfully collected the data from 48 sampling points both during high and low tides events coincide to full and new moon conditions. All data collected were analyzed using cluster analysis and TRIX index. The results show that spatially the study area was divided into two clusters namely K1 (shore territory) and K2 (central area included the corner of Pegametan Bay) with the TRIX indexs were 4.97 \pm 0.92 and 5.51 \pm 0.90 , respectively. While based on temporal analysis, the study area was devided into two groups: August (A1) and SeptemberOctober (A2) with the TRIX index 4.28 \pm 0.99 and 5.78 \pm 0.27 , respectively. Based on the results of cluster analysis and TRIX index showed clearly that K1 cluster area was better than K2 cluster area. K1 cluster is still suitable for marine fish cage culture; but the used of integrated multi-trophic aquaculture (IMTA) is recommended in order to maintain water carrying capacity in Pegametan Bay. Temporal trend was showed that the pattern which followed water mass fluctuation at high/low tides, and the schedule of massive fishes death in a year; it was significant in August

\# Korespondensi: Departemen Manajemen Sumber Daya Perairan, Fakultas Perikanan dan Ilmu Kelautan, Institut Pertanian Bogor Jl. Agatis, Kampus IPB Dramaga, Bogor 16680, Indonesia.

E-mail: radiarta@yahoo.com 
(A1) to September-October (A2). The results of this study could provide information about status trophic of Pegametan Bay that could be use for improving the management of the area for sustainable marine aquaculture.

KEYWORDS: $\quad$ variability, cluster analysis, TRIX, trophic state, IMTA, Pegametan Bay

\section{PENDAHULUAN}

Pemanfaatan kawasan Teluk Pegametan didominasi oleh budidaya ikan dalam keramba jaring apung (KJA), sebagian kecil oleh kegiatan penangkapan dan budidaya rumput laut yang kini sangat berkembang pesat. Kegiatan-kegiatan tersebut khususnya adalah KJA yang dominan terdapat di teluk ini sangat berpotensi menimbulkan gejala eutrofikasi atau peningkatan status trofik perairan. Hasil penelitian terkini menunjukkan budidaya ikan dalam KJA di Teluk Pegametan berkontribusi memasukkan beban nutrien sebesar $0,7 \mathrm{~kg} /$ ton ikan/hari dan $0,28 \mathrm{~kg} /$ ton ikan/hari (Sutarmat et al., 2014). Beban nutrien N (nitrat) dan $P$ (fosfat) sangat erat korelasinya dengan kenaikan status trofik atau kesuburan perairan di segala jenis perairan (Salas et al., 2008).

Karakteristik lokasi penelitian ini yakni kawasan teluk dapat dijadikan sebagai kawasan untuk menghitung status trofik dengan indeks TRIX (Vollenwider et al., 1998). Kondisi yang memungkinkan digunakannya indeks ini telah direferensikan atas suatu teluk yang dinamis dibandingkan jenis perairan lainnya sehingga nutrien sebagai faktor pembatas (limiting factor) N dan P terhadap status trofik menjadi sangat berfluktuasi (Taylor et al., 1995). Fluktuasi ini dapat dipengaruhi oleh arus yang biasanya terjadi ketika peralihan musim sehingga penggunaan indeks TRIX yang memasukkan kedua nutrien $\mathrm{N}$ dan $\mathrm{P}$ ke dalam formula indeksnya sangat relevan (Saravi et al., 2012). Tidak hanya faktor pembatas nutrien $\mathrm{N}$ dan $\mathrm{P}$, akan tetapi implikasi terhadap asupannya yakni begitu sensitifnya parameter klorofil-a saat terjadi kenaikan status yang diiringi beban nutrien yang turut meningkat (Boyer et al., 2009). Pertimbangan untuk parameter lainnya yaitu oksigen yang memungkinkan melengkapi keadaan kritis ketika kondisi ini turut diikuti penurunan konsentrasinya hingga ke level hypoxia (Boesch et al., 2001).

Identifikasi status trofik tidak hanya dilihat pada suatu nilai indeks TRIX yang mereferensikan status trofik di Teluk Pegametan, Singaraja, Bali, akan tetapi fluktuasinya melalui tren variabilitas baik spasial maupun temporal. Secara spasial dilihat berdasarkan klasternya yang mengindikasi setiap area memiliki indeks secara indentik (Wu et al., 2010). Selanjutnya secara temporal ditendesikan pada fluktuasi air saat pasang surut dalam kurun waktu penelitian dan pengamatan dilaksanakan. Pengkondisian ini pada dasarnya mengungkapkan tren variabilitas indeks dan menjadi petunjuk bagi kondisi status trofik (Scavia \& Bricker, 2006). Terdapat variabilitas status trofik biasanya terjadi di lokasi teluk dan pesisir (Souza et al., 2003). Hasil yang dapat diambil dari penelitian ini meliputi status trofik yang bervariasi baik secara spasial dan temporal sebagai sebuah bentuk tren status di Teluk Pegametan, Singaraja, Bali.

Penelitian ini bertujuan mendapatkan variasi indeks TRIX lalu mengungkapkan tren variabilitas status trofik baik secara spasial dan temporal. Kedua tren tersebut adalah informasi dasar untuk pengelolaan kawasan teluk. Tren status trofik secara spasial akan mendapatkan kawasan mana yang memiliki kondisi trofik yang paling baik sedangkan tren temporal adalah penelusuran waktu terhadap variabilitas status tropik. Terbaginya kawasan atas dasar tren status trofik secara spasial memberikan solusi pengembangan budidaya laut untuk kawasan yang masih cukup baik berdasarkan kualitas perairannya. Solusi untuk informasi tren temporal mampu menerangkan Teluk Pegametan memiliki potensi untuk melakukan suatu purifikasi kualitas perairan secara alami.

\section{BAHAN DAN METODE}

Penelitian ini dilaksanakan di Teluk Pegametan Desa Sumberkima Kecamatan Gerokgak Kabupaten Buleleng, Bali (Gambar 1). Lokasi teluk ini adalah termasuk bagian dari teluk besar di Sumberkima dengan luas keseluruhan sekitar 935 ha. Teluk Pegametan hanya memiliki luas berkisar 340 ha (Hanafi et al., 2006). Kegiatan budidaya laut terkini sebagian besar didominasi oleh keramba jaring apung (KJA) dengan komoditas ikan kerapu dan kakap. Total KJA kini mencapai 860 unit tersebar hampir di seluruh teluk dan kondisi aktual teluk mengalami dua kali pasang surut dalam sehari (semidiurnal) dengan fluktuasi air rata-rata tidak lebih dari $1 \mathrm{~m}$, serta kedalaman berkisar 15-30 meter (Sutarmat et al., 2014).

\section{Pengumpulan Data}

\section{Spasial}

Penempatan 48 titik pengamatan secara spasial didasari oleh karakteristik dan intensitas pemanfaatan lokasi teluk yang ada (Gambar 1). Pemilihan lokasi titik pengamatan disebar secara acak dengan beberapa pertimbangan yaitu: (1) daerah inlet atau masuknya air laut ketika surut terjadi dan merupakan area terdekat dari pelabuhan kapal atau perahu pekerja KJA dan nelayan; (2) lokasi paling sedikit terdapat KJA; 

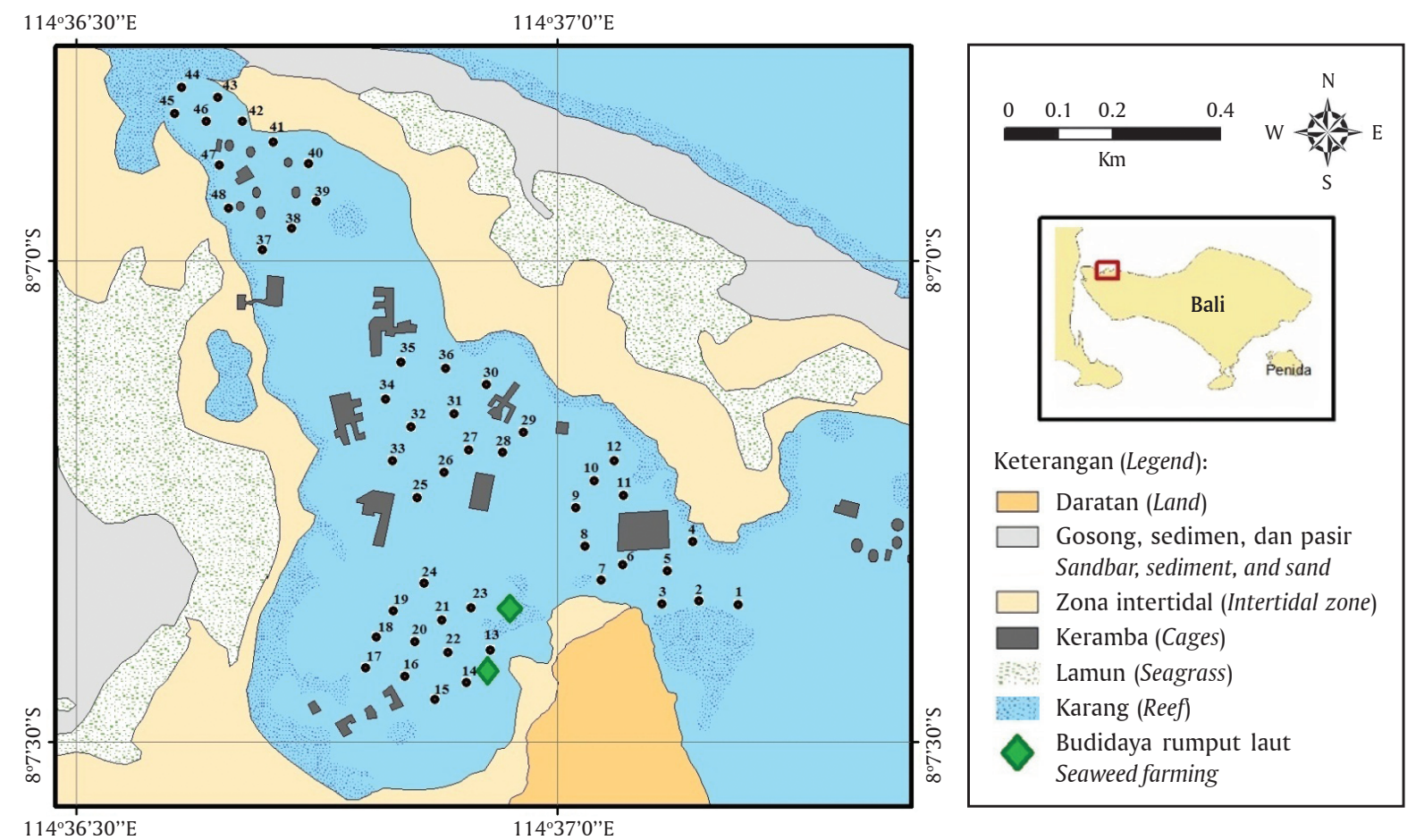

Gambar 1. Lokasi penelitian di Teluk Pegametan, Bali dan sebaran titik pengamatan (Sumber: Google earth)

Figure 1. Study location in Pegametan Bay, Bali and distribution of sampling stations (Sources: Google earth)

(3) lokasi terpadat untuk kegiatan KJA sekaligus jalur lalu lintas utama; dan (4) adalah lokasi paling ujung dan pada saat surut terendah kemunculan pasir dan daratan lainnya akan menutupi akses air keluar teluk.

\section{Temporal}

Pengamatan secara temporal dilakukan melalui penetapan waktu sampling berdasarkan kondisi pasang tertinggi dan surut terendah dengan pertimbangan keduanya terjadi di saat bulan purnama dan gelap. Pengamatan dilakukan tiga kali ulangan pada saat bulan purnama (P) dan gelap (G). Jarak waktu antara setiap ulangan (bulan purnama-gelap) adalah 1415 hari. Total waktu penelitian adalah selama tiga bulan: Agustus-Oktober 2014. Kisaran pasang dan surut terjadi mengikuti waktu penelitian yakni pada bulan Agustus 67 - (-90) cm saat bulan purnama (P1) dan 54 - (-68) cm saat bulan gelap (G1). Pada bulan September kisaran pasang surut adalah $31-(-57) \mathrm{cm}$ bulan purnama (P2) dan 29 - (-53) cm bulan gelap (G2). Bulan Oktober kondisi pasang surut mencapai $17-(-39) \mathrm{cm}$ di bulan purnama (P3) dan 9 - (-39) cm di bulan gelap (G3).

\section{Parameter yang Diamati}

Data yang dikumpulkan selama penelitian adalah parameter fisika, kimia, dan biologi perairan. Parameter fisika yang diukur meliputi: kecerahan, salinitas, suhu, dan arus. Pengukuran kecerahan menggunakan Secchi Disk, salinitas dengan refraktometer, suhu dan oksigen terlarut (DO) menggunakan DO-meter, serta arus beserta arahnya dengan metode melampungkan sebuah alat yang dicatat jaraknya selama sepuluh menit. Parameter kimia yang diukur meliputi: $\mathrm{NO}_{3}, \mathrm{NO}_{2}$, $\mathrm{NH}_{3}$, dan DIP atau $\mathrm{PO}_{4}$. Sedangkan parameter biologi adalah klorofil-a (Chl-a). Parameter kimia dan biologi dianalisis di Balai Penelitian Oseanografi Laut (BPOL), Jembrana, Bali dan di Laboratorium Kimia Fakultas MIPA Universitas Brawijaya, Malang.

\section{Analisis Data}

Data yang dikumpulkan dianalisis secara deskriptif, analisis klaster dan indeks TRIX. Analisis deskriptif meliputi: rataan, standar deviasi, dan kisaran nilainya. Nilai-nilai tersebut dibandingkan dengan standar baku mutu menurut Kepmen LH No. 51 Tahun 2004. Pembandingan hasil dilihat berdasarkan batas maksimum parameter-parameter yang harus dipenuhi menurut baku mutu tersebut. Hasil ini kemudian dibahas secara deskriptif yang ditampilkan dalam bentuk tabel.

Analisis klaster digunakan untuk mengetahui karakteristik kawasan Teluk Pegametan. Analisis klaster adalah analisis multivariat yang sangat berguna untuk mengelompokkan menurut kedekatan nilai parameter-parameter di setiap lokasi (spasial) dan waktu penelitian (temporal) (Kamble \& Vijay, 2011). Analisis klaster yang digunakan dalam penelitian ini adalah melalui hierarchical cluster analysis dengan hasil berupa nilai kedekatan parameter atau homoge- 
nitas (within-group cluster) terdeskripsi di Squared Euclidean Distance Combine. Berdasarkan hasil ini ditunjukkan kelompok parameter-parameter kualitas air di setiap lokasi dan waktu terkarakteristik oleh dendogram. Dendogram ini membagi semua kelompok secara menyeluruh melalui sebuah bentuk bagannya.

Penentuan status trofik di Teluk Pegametan dilakukan melalui indeks TRIX (Vollenweider et al., 1998). Sebagai salah satu metode identifikasi kualitas perairan berdasarkan status trofik atau kesuburannya (Tabel 1). Indeks TRIX melibatkan parameter DIN dan DIP atau $\mathrm{PO}_{4}, \% \mathrm{O}_{2}$, dan Chl-a. Indeks TRIX dihitung dengan persamaan berikut:

$$
\text { TRIX }=\frac{\log \left(\text { Chl-a } \times \% \mathrm{O}_{2} \times \text { DIN } \times \text { DIP }\right)+1.5}{1.2}
$$

di mana:

$\% \mathrm{O}_{2}($ Oksigen saturasi $)=\{\mathrm{DO}(\mathrm{Oksigen}$ terlarut $) / \mathrm{DOi}(\mathrm{Ok}-$ sigen absolut) $\} \times 100 \%$

DOi (Oksigen absolut) $=14.62-0.37\left(\mathrm{~T}^{\circ} \mathrm{C}\right)+0.0045(\mathrm{~T}$

$\left.{ }^{\circ} \mathrm{C}\right)^{2}-0.097($ Sal $)+0.002\left(\mathrm{~T}^{\circ} \mathrm{C}\right)($ Sal $)+0.0003(\text { Sal })^{2}$

(Weiss, 1970)

DIN $=\mathrm{NH}_{3}+\mathrm{NO}_{2}+\mathrm{NO}_{3}$

$\mathrm{DIP}=\mathrm{PO}_{4}$

Chl-a $=$ Klorofil a

$\mathrm{K}=1.5$ (Faktor skala 0-10, Tabel 1)

$\mathrm{M}=1.2$ (Konstanta)

Tabel 1. Faktor skala indeks TRIX

Table 1. Scale factor TRIX index

\begin{tabular}{cc}
\hline Nilai TRIX & \multicolumn{1}{c}{ Status trofik } \\
TRIX values & Trophic status \\
\hline $0<$ TRIX $<4$ & Oligotrofik \\
$4<$ TRIX $<5$ & Mesotrofik \\
$5<$ TRIX $<6$ & Eutrofik \\
$6<$ TRIX $<10$ & Hipertrofik \\
\hline
\end{tabular}

\section{HASIL DAN BAHASAN}

\section{Kondisi Kualitas Perairan}

Data kualitas perairan memiliki korelasi erat terhadap status trofik dan sangat memungkinkan untuk dijadikan sebuah indikator penunjuk status trofik (Tsuzuki, 2006). Kualitas perairan di Teluk Pegametan ditunjukkan pada Tabel 2. Konsentrasi nitrat $\left(\mathrm{N}-\mathrm{NO}_{3}\right)$ telah melewati batas baku mutu yang ditetapkan $<0,008 \mathrm{mg} / \mathrm{L}$. Ini mengindikasi bahwa teluk berada kondisi yang buruk untuk cemaran nutrien N. Konsentrasi $\mathrm{N}$ yang besar ini dapat disebabkan oleh kegiatan KJA yang mendominasi teluk. Limbah nutrien yang berasal dari kegiatan KJA sangat potensial menaikkan status trofik perairan hingga dapat menyebabkan eutrofikasi (Huang et al., 2011). Cemaran nu- trien $\mathrm{P}$ juga terlihat cukup tinggi dan berpotensi sama dengan nutrien $\mathrm{N}$ dalam memicu eutrofikasi (Tabel 2). Nutrien $\mathrm{P}\left(\mathrm{P}_{-} \mathrm{PO}_{4}\right)$ telah menunjukkan melewati batas baku mutu $<0,015 \mathrm{mg} / \mathrm{L}$. Walaupun konsentrasi $\mathrm{N}$ dan $\mathrm{P}$ memicu kenaikan status trofik hingga dapat mengalami kondisi eutrof, akan tetapi kecenderungan faktor $\mathrm{N}$ lebih signifikan dibandingkan $\mathrm{P}$ untuk lokasi pesisir dan teluk (Howarth \& Marino, 2006). Pernyataan ini telah dibuktikan pada Tabel 2 yang mengungkapkan $\mathrm{N}$ secara dominan lebih tinggi konsentrasinya dibandingkan $\mathrm{P}$ di mana $\mathrm{N}$ sendiri didominasi oleh konsentrasi $\mathrm{NO}_{3}$ sedangkan $\mathrm{P}$ adalah $\mathrm{PO}_{4}$. Rasio dari kedua faktor nutrien $\mathrm{N}$ dan $\mathrm{P}$ memberikan petunjuk nutrien mana yang harus ditekan jumlahnya atau beban dalam pengelolaan perairan (Paerl, 2009). Rasio antara N dan P di Teluk Pegametan terlihat lebih mengarah pada faktor $\mathrm{N}$ dibandingkan $\mathrm{P}$ berdasarkan tingginya konsentrasi nitrat $\left(\mathrm{N}-\mathrm{NO}_{3}\right)$ dibandingkan fosfat $\left(\mathrm{P}^{-} \mathrm{PO}_{4}\right)$ sehingga ini dapat memastikan nutrien $\mathrm{N}$ sebagai nutrien utama yang harus diperhatikan. Parameter lainnya juga menunjukkan nilai yang bervariasi di antaranya suhu, salinitas, arus, DO, chl-a, dan kecerahan. Pada dasarnya perairan teluk cenderung dinamis dan dapat dipastikan memiliki potensi untuk mempurifikasi perairan secara alami di waktu-waktu tertentu.

\section{Analisis Klaster}

\section{Spasial}

Sebanyak 48 titik pengamatan yang diambil di Teluk Pegametan, Singaraja, Bali telah dianalisis klaster dan hasilnya terbagi menjadi dua wilayah yakni: klaster K1 dan K2. Analisis klaster menurut tingkat kesamaan data (within-group cluster) pada K1 terdiri stasiun 1-4, 9-20, 25, dan 27-29 ( $\mathrm{N}=20)$ sedangkan pada $\mathrm{K} 2$ adalah 5-8, 21-24, 26, dan 30-48 ( $\mathrm{N}=28)$. Hasil klaster analisis yang ditunjukkan dalam dendogram disajikan pada Gambar 2.

Kecenderungan spasial biasanya akan mengikuti pola distribusi massa air secara horizontal sehingga dimungkinkan setiap wilayah memiliki perbedaan kualitas dan status tingkat kesuburan perairannya (Seisdedo et al., 2014). Sebaran stasiun atau titik pengamatan telah mengikuti pola arus yang ada di Teluk Pegametan dan sebagai acuan untuk mengetahui tren status trofik secara spasial. Arus dan arahnya sangat berperan memengaruhi tren variabilitas status trofik di mana kondisi terbaik ketika arus yang tinggi disertai arah yang terkonsentrasi diduga memiliki kualitas airnya lebih baik dibandingkan dengan keadaan arus rendah, serta arahnya yang tidak terkonsentrasi (Jayachandran \& Nandan, 2011). Pada dendogram within groups untuk hierarchical cluster analysis mengungkapkan bahwa Teluk Pegametan telah 


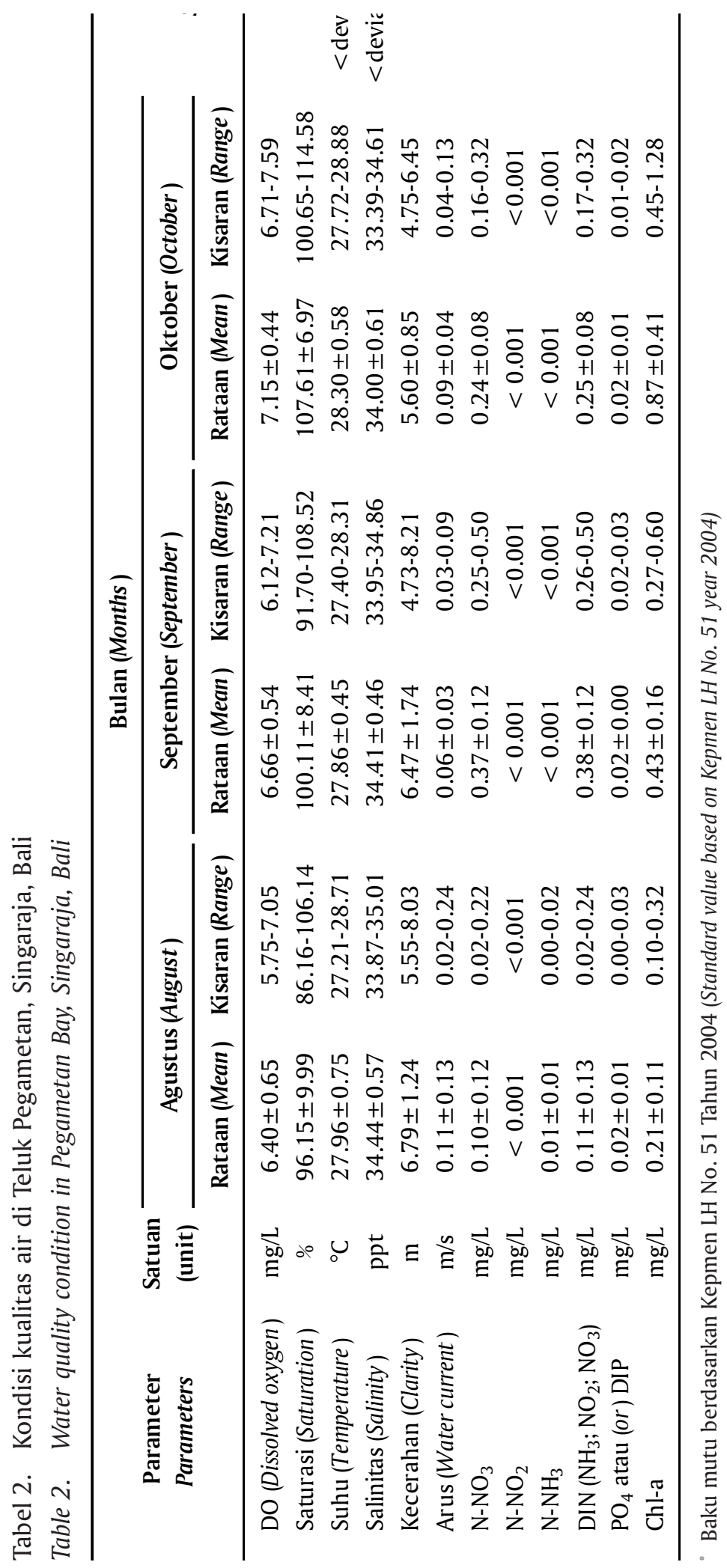




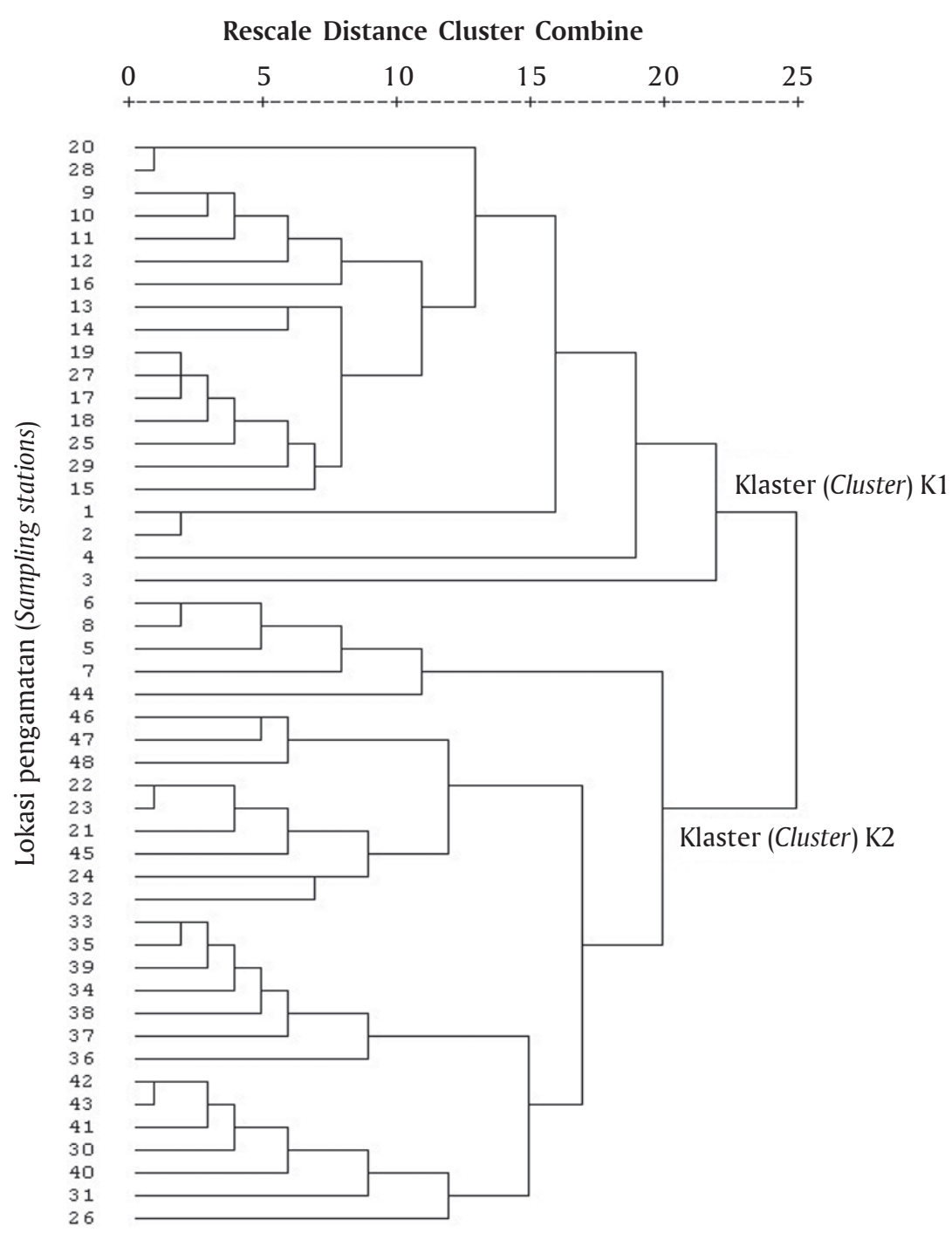

Gambar 2. Dendogram pengelompokkan wilayah di Teluk Pegametan

Figure 2. Dendograms of clustering locations in Pegametan Bay

terbagi menjadi dua wilayah (K1 \& K2) di mana keduanya memiliki karakteristik kualitas air yang berbeda (Gambar 2). Terbaginya wilayah klaster K1 dan K2 melalui lingkupan wilayahnya seperti masuknya air pada teluk (inlet) tergabung dengan wilayah pesisir teluk menjadi kawasan K1 sedangkan kawasan K2 terdiri atas ujung teluk beserta lokasi tengah teluk. Pembagian wilayah ini secara jelas dipetakan pada Gambar 3 sebagai penunjuk terhadap tren variabilitas status trofik secara spasial.

Wilayah $\mathrm{K} 1$ cenderung memiliki kualitas perairan yang lebih baik dibandingkan dengan $\mathrm{K} 2$. Hal ini dikarenakan wilayah $\mathrm{K} 1$ pada gabungan bagian inlet dan pesisir memiliki intensitas pembilasan tinggi dibandingkan wilayah $\mathrm{K} 2$ yang terdiri atas bagian tengah dan ujung dalam teluk. Bukti terlihat dari rata-rata kecepatan arus maksimal pada $\mathrm{K} 1$ adalah $0,20 \mathrm{~m} / \mathrm{s}$ sedangkan $\mathrm{K} 2$ hanya $0,15 \mathrm{~m} / \mathrm{s}$. Selain itu, pada K1 di bagian pesisir teluk selain zona yang terdekat inlet, kualitas perairan cukup baik karena terdapat beberapa aktivitas budidaya rumput laut berdampak positif bagi perairan. Keberadaan budidaya ini mampu menyerap nutrien secara signifikan yang berasal dari sisa pakan budidaya laut keramba jaring apung (KJA) sehingga kualitas perairan menjadi lebih baik (Radiarta et al., 2014). Pada wilayah K2 adalah kebalikan kualitas perairan yang lebih buruk dari K1. Selain lokasi K2 adalah rata-rata memiliki kepadatan tinggi untuk kegiatan KJA, juga didorong dari aktivitas penunjang seperti wilayah pusat transportasi para pekerja KJA, serta stasiun 5, 6, dan 7 (K2) adalah wilayah terdekat dengan labuhan kapal dari pemilik KJA dan nelayan setempat (Gambar 1). Kondisi pada wilayah K2 juga diperburuk oleh akses keluaran air pada lokasi ujung teluk meliputi stasiun-stasiun terdekat $43,44,45$, dan 46 yang ketika surut terendah akan dapat tertutupi oleh daratan yang muncul sehingga nutrien-nutrien yang seharusnya terbilas keluar dari teluk akan terperangkap di wilayah ini. Pengaruh alur pembilasan 


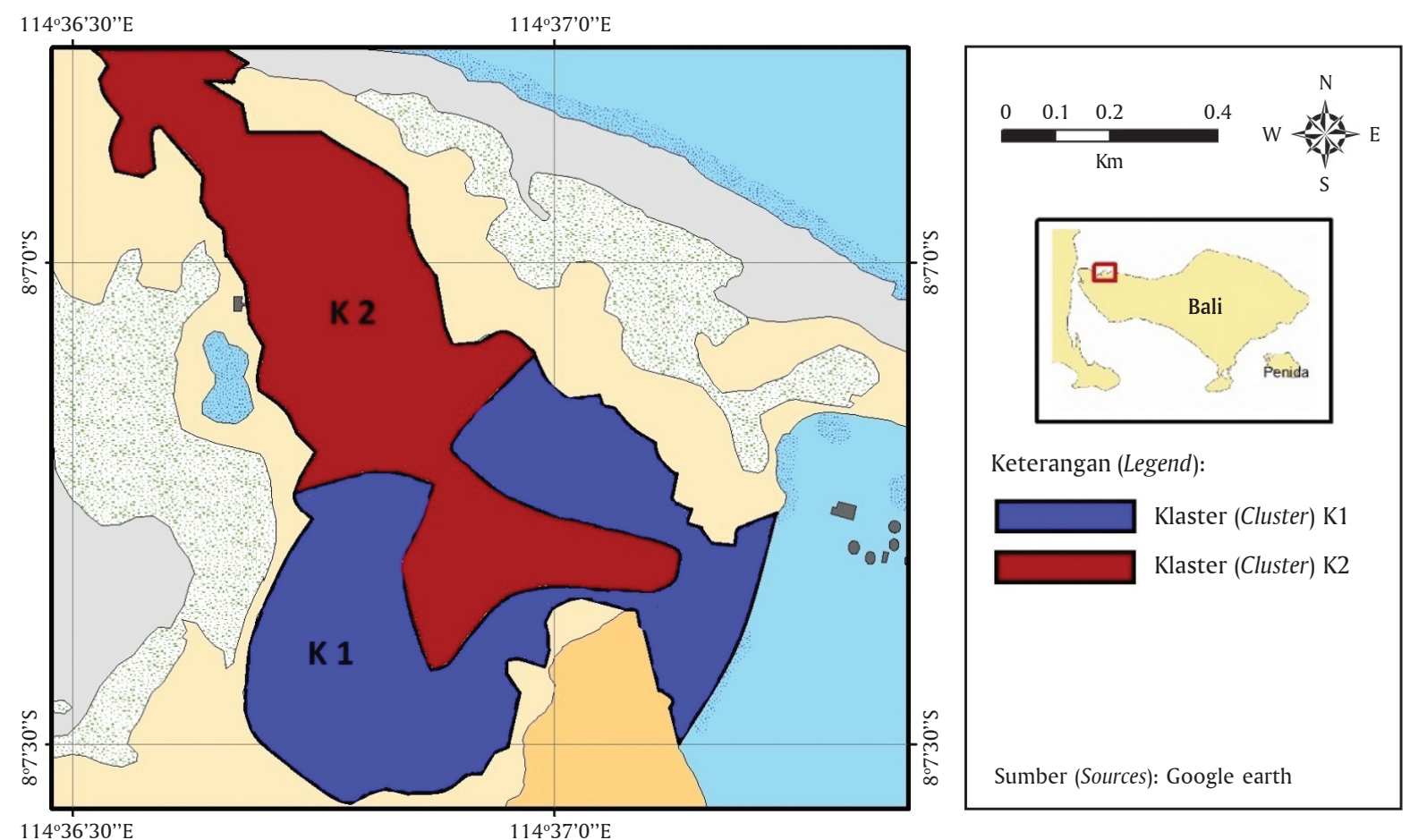

Gambar 3. Pengelompokkan wilayah di Teluk Pegametan berdasarkan parameter kualitas air

Figure 3. $\quad$ Clustering locations in Pegametan Bay based on water quality

dan imbas budidaya rumput laut sehingga klaster secara spasial terbagi atas $\mathrm{K} 1$ dan $\mathrm{K} 2$ memungkinkan terdapat variabilitas status trofik di kawasan Teluk Pegametan berdasarkan klaster wilayah K1 dan K2.

\section{Temporal}

Secara temporal analisis klaster dilakukan berdasarkan variasi nilai parameter-parameter kualitas air di Teluk Pegametan (Tabel 2). Hasil analisis klaster secara temporal dengan metode within-groups untuk hierarchical cluster analysis telah terbagi menjadi dua yakni A1 pada bulan Agustus sedangkan A2 yakni gabungan antara September dan Oktober di Teluk Pegametan (Gambar 4).

Menurut Wei et al. (2010), bahwa parameter fisik seperti arus diikuti fluktuasi pasang surut merupakan penentu kualitas air secara temporal atau periodik untuk suatu perairan pesisir atau teluk. Pasang surut secara intens dapat memengaruhi kondisi purifikasi perairan sekaligus pembilasan bahan-bahan organik (Krivokapic et al., 2011). Faktor intensitas pasang dan surut memengaruhi kualitas suatu perairan teluk dan akan signifikan ketika mengalami peralihan musim (Saravi et al., 2012). Dendogram pada Gambar 4 yang membagi kelompok temporal A1 dan A2 berdasarkan kesignifikan kualitas air di selang waktu penelitian (Agustus, September, dan Oktober). Di bulan Agustus A1 cenderung intensitas pasang surut tertinggi dan merefleksikan kondisi perairan terbaik, sedangkan antara bulan September dan Okto- ber kondisi pasang dan surut relatif menyerupai dan memang cukup rendah (Gambar 5).

Pemilihan waktu sampling Agustus-Oktober 2014 diyakini sebagai peralihan siklus angin Timur ke Barat (Emiyati et al., 2014). Di musim peralihan biasanya dapat terlihat sebuah tren perbedaan kualitas perairan dan ini diikuti oleh variabilitas status trofiknya (Boikova et al., 2008). Variabilitas ini adalah bentuk suatu tren yang signifikan mengikuti pergolakan massa air yang ditandai dengan perbedaan intensitas pasang surut perairan (Mizerkowski et al., 2012). Bukti perbedaan kualitas dan dugaan variabilitas dari status trofik di Teluk Pegametan terlihat dari faktor nutrien dan klorofil di mana pada Tabel 2 menunjukkan konsentrasi nutrien $\mathrm{N}$ terlarut (DIN) yang signifikan mengalami kenaikan saat bulan Agustus ke September dan sedikit mengalami penurunan saat bulan Oktober; dan konsentrasi klorofil (Chl-a) juga turut meningkat selang waktu tersebut (Tabel 2). Parameter klorofil begitu sensitif terhadap kenaikan kesuburan atau status trofik perairan seiring beban nutrien yang semakin tinggi (Boyer et al., 2009).

\section{Status Tingkat Trofik (Indeks TRIX)}

Semakin tinggi intensitas atau kepadatan kegiatan antropogenik memungkinkan wilayah tersebut akan mengalami kenaikan status trofik secara berlebihan (Selman et al., 2008). Teluk Pegametan telah mengalami pemusatan populasi kegiatan keramba jaring apung (KJA) di bagian tengah teluk dan seba- 


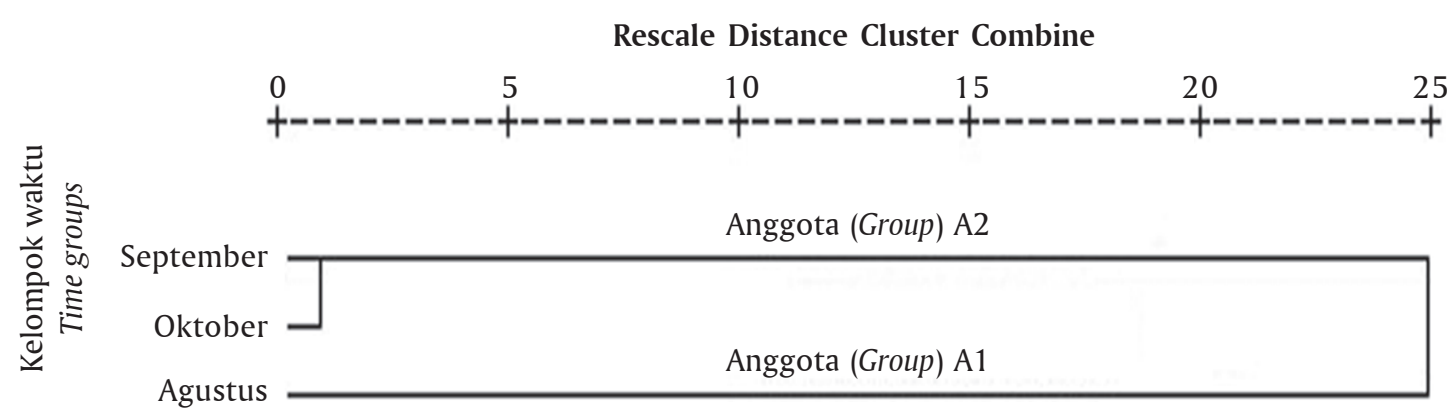

Gambar 4. Dendogram pengelompokkan periode penelitian di Teluk Pegametan

Figure 4. Dendogram of clustering based on study periods in Pegametan Bay

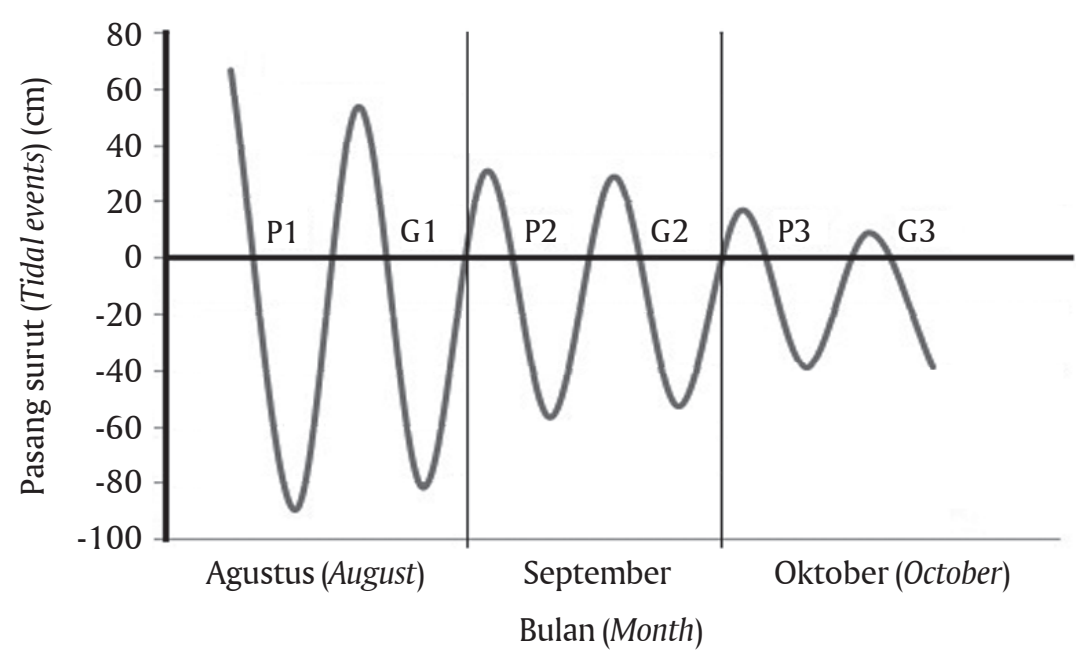

Gambar 5. Kondisi pasang dan surut selama Agustus-Oktober di Teluk Pegametan

Figure 5. Tidal events during August-October in Pegametan Bay

gian kecil terdapat di dekat pesisir teluk sehingga ada dugaan kawasan keduanya memiliki perbedaan dan membentuk suatu tren variabilitas status trofik secara spasial di Teluk Pegametan. Pembuktian dugaan tersebut tersaji berdasarkan analisis klaster (Gambar 3) yang membagi kawasan teluk ini menjadi dua bagian yakni: K1 dan K2. Hasil penentuan status trofik melalui indeks TRIX turut mempertegas hasil bahwa memang tren variabilitas secara spasial telah terdapat di Teluk Pegametan (Gambar 6).

Pada K1 dan K2 memiliki nilai indeks TRIX yang signifikan berbeda yakni $\mathrm{K} 1=4,97 \pm 0,92$ sedangkan $\mathrm{K} 2=5,51 \pm 0,90$. Berdasarkan faktor skala status di mana K1 hampir berada di status mesotrofik (4-5) dan K2 yakni 5-6 berada di status eutrofik (Tabel 1). Wilayah klaster K1 adalah kawasan inlet atau masuknya air laut secara rutin di teluk ini dan kawasan pesisir dalam teluk di mana kawasan yang hanya terdapat aktivitas budidaya rumput laut. Sementara itu, wilayah klaster $\mathrm{K} 2$ terdiri atas kawasan tengah dan ujung teluk. Gambar 6 menunjukkan hasil penentuan status trofik TRIX yang selaras dengan analisis klaster menurut kualitas perairan secara spasial K1 dan K2. Dugaan sebelumnya dari analisis klaster se- cara spasial untuk K1 cenderung lebih baik dibandingkan K2 terbukti melalui indeks TRIX dan mencerminkan status trofiknya. Konfirmasi ini merekomendasi untuk memanfaatkan wilayah $\mathrm{K} 1$ daripada K2 atau memindahkan sebagian usaha KJA pada wilayah $\mathrm{K} 1$, serta mengadopsi budidaya yang berbasis IMTA (integrated multi trophic aquaculture). Pada metode budidaya IMTA ini memanfaatkan trofik level rendah seperti rumput laut sebagai penyerap nutrien berlebih dari sisa pakan yang terbuang sehingga kualitas perairan menjadi lebih sehat (Radiarta et al., 2014). Hal ini dibuktikan pada penentuan indeks TRIX di kawasan K1 yang terdapat aktivitas budidaya rumput laut memiliki status trofik lebih rendah dibandingkan pada kawasan tanpa aktivitas ini untuk wilayah klaster K2.

Pasang dan surut (Gambar 4) adalah suatu dugaan untuk klaster secara temporal dan turut mengikuti pola fluktuasinya. Analisis klaster secara temporal ini sebelumnya berdasarkan kondisi kualitas air pada bulan Agustus, September, dan Oktober lalu dilakukan analisis klaster yang ditampilkan dalam bentuk dendogram (Gambar 5). Berdasarkan dendogram terbagi atas A1 untuk bulan Agustus dan A2 Septem- 


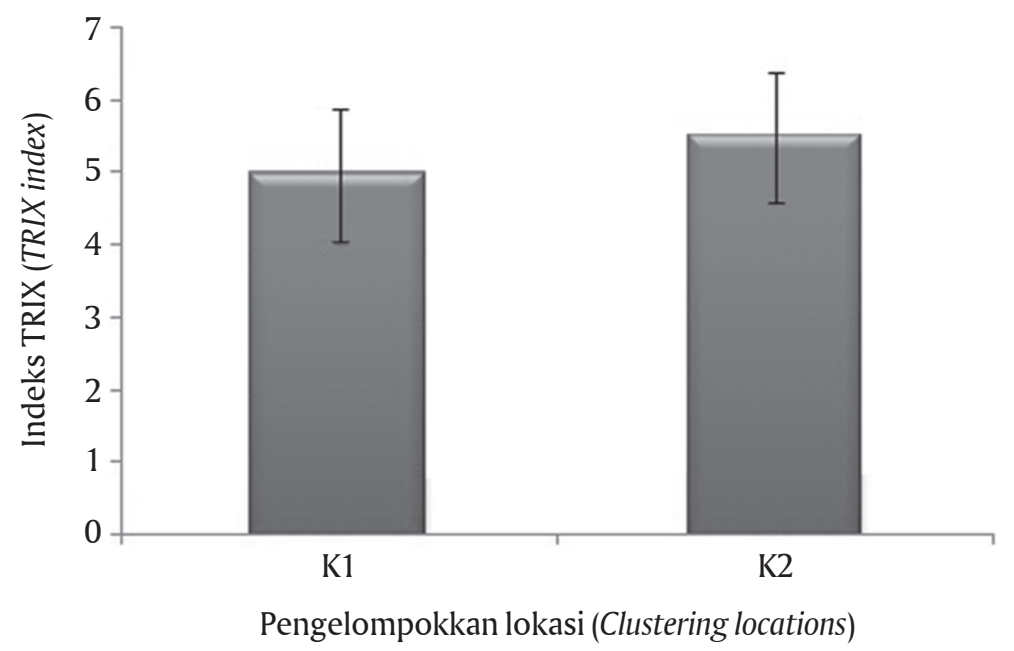

Gambar 6. Indeks TRIX berdasarkan klaster lokasi antara stasiun-stasiun sampling

Figure 6. TRIX index on clustering locations among sampling stations

ber-Oktober. Pembagian ini signifikan untuk penentuan indeks TRIX dan hasilnya tersaji pada Gambar 7.

Hasil yang diperlihatkan pada Gambar 7 adalah A1 (Agustus) memiliki indeks TRIX $=4,28 \pm 0,99$ dan A2 (September-Oktober) indeks TRIX $=5,78 \pm 0,27$. Berdasarkan faktor skala yang ditunjukkan A1 berada di kisaran 4-5 dan statusnya adalah mesotrofik sedangkan A2 di kisaran 5-6 dan ini berstatus eutrofik (Tabel 1). Jika melihat perbedaan ini maka fluktuasi air atau pasang surut sangat memengaruhi nilai indeks TRIX seiring variasi kualitas perairan di setiap klaster A1 dan A2. Pada bulan Agustus (A1) secara signifikan terlihat pasang surut yang terlihat sangat fluktuatif (Gambar 4) menunjukkan kondisi yang terbaik bagi perairan dan ini dibuktikan pada penentuan indeks TRIX, serta data kualitas perairan di bulan ini. Sedangkan September-Oktober (A2) adalah sebaliknya dengan indeks TRIX mengalami kenaikan se- telah bulan Agustus (Gambar 7). Hasil ini mengungkapkan bahwa pasang surut secara temporal signifikan menentukan tren variabilitas status trofik secara temporal dan ini sebenarnya telah dibuktikan sebelumnya oleh Alves et al. (2013). Berdasarkan kajian Alves et al. (2013) menunjukkan bahwa pasang dan surut secara temporal terlihat sangat mampu menunjukkan tren variabilitas melalui variasi nilai TRIX dari 2,26-6,43 yang dilakukan di pesisir Kota Penambuco, Brazil selama setahun. Di tempat berbeda yakni di pesisir Kota Recife, Brazil status trofik juga mengalami variabilitas dari 3,9-6,5 dengan durasi waktu yang sama (Montes et al., 2011). Di Teluk Pegametan pola tren variabilitas trofik secara temporal (Gambar 7) hampir mengikuti jadwal kematian massal ikan yang mana puncaknya biasa terjadi pada bulan September-Januari (Radiarta \& Erlania, 2015). Secara logis hal ini menunjukkan bahwa sebelum terjadinya kematian massal akan diiringi kenaikan

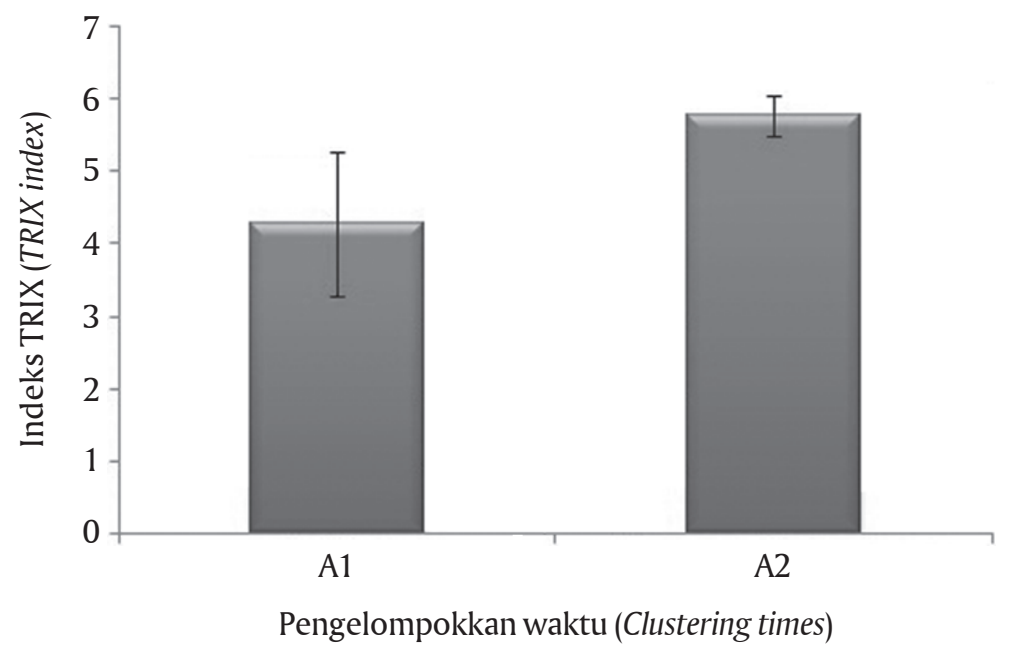

Gambar 7. Indeks TRIX berdasarkan klaster waktu penelitian

Figure 7. TRIX index on clustering of times study 
status trofik (Gambar 7) dan penurunan kualitas perairan sehingga ada dugaan hal ini dapat dijadikan sebuah indikator prediksi untuk variabilitas status trofik secara temporal.

\section{Perspektif Status Trofik Terhadap Pengelolaan Kawasan Teluk Pegametan}

Dalam pengembangan budidaya keramba jaring apung (KJA) secara strategis lokasi K1 lebih direkomendasikan dibandingkan $\mathrm{K} 2$; dengan pertimbangan kondisi kualitas perairan dan status trofik masih bisa menampung beban nutrien dari sisa pakan KJA. Kemudian secara temporal, adanya variasi status trofik yang terjadi (A1 dan A2) dapat ditelusuri bahwa Teluk Pegametan ini memiliki jadwal untuk purifikasi kualitas perairan seiring jadwal dari kematian massal ikan yang terjadi. Selain informasi tren variabilitas, kondisi kualitas perairan secara umum tinggi akan nutrien pemicu peningkatan status kesuburan atau trofik sehingga untuk perkembangan budidaya KJA diperlukan sistem yang ramah lingkungan yaitu: budidaya KJA berbasis integrated multi-trophic aquaculture (IMTA) guna mendukung kualitas air di lokasi ini menjadi lebih baik, sehingga aktivitas budidaya ikan dapat berkelanjutan.

\section{KESIMPULAN}

Kualitas perairan secara umum di Teluk Pegametan tidak cukup sehat dengan dominasi cemaran nutrien $\mathrm{N}$ (nitrat) yang tinggi dibandingkan $\mathrm{P}$ (fosfat). Hasil analisis klaster dan indeks TRIX secara spasial menunjukkan bahwa kawasan K1 (yang melingkupi wilayah inlet dan pesisir) memiliki kondisi yang lebih baik dibandingkan dengan kawasan K2 (wilayah ujung serta bagian dalam teluk). Sedangkan secara temporal menunjukkan bahwa kondisi perairan bulan Agustus (A1) lebih baik dibandingkan bulan SeptemberOktober (A2). Hasil dari penelitian ini dapat memberikan informasi dasar yang berguna bagi pengelolaan kawasan Teluk Pengametan, sehingga aktivitas budidaya laut yang berkembang dapat berkelanjutan.

\section{UCAPAN TERIMA KASIH}

Penulis mengucapkan terima kasih kepada Bapak Tatam Sutarmat dan staf KJA Balai Besar Penelitian dan Pengembangan Budidaya Laut Gondol yang telah membantu sepenuhnya dalam pengumpulan data lapangan.

\section{DAFTAR ACUAN}

Alves, G., Montes, F.M., Gaspar, F., Gomes, J., \& Feitosa, F. (2013). Journal of Coastal Research, Doi: 10.2112/s165-002.1.

Boesch, F.D., Brinsfield, R. B., \& Magnien, R.E. (2001).
Chesapake Bay Eutrophication scientific understanding, ecosystem resotroration, and challenges for agriculture. J. Environ. Qual., 30, 303-320.

Boikova, E., Botva, U., \& Licite, V. (2008). Implemantation of trophic status index in brackish water quality assessment of baltic coastal waters. Proc. of Latvian Acc of Sci. Sec. B., 62(3)-(656), 115-119. Doi: 10.2478/v10046-008-0016-z.

Boyer, J.N., Kelbe, C.R., Ortner, P.B., \& Rudnick D.T. (2009). Phytoplankton bloom status: chlorophyll a biomass as an indicator of water quality condition in Southern Estuaries of Florida, United State of America. Ecology Indicators 9s. Doi:10. 1016/j.ecolind.2008.11.013.

Emiyati, Kuncoro, T.S., Manopo, A.K.S., Budhiman, S., \& Hasyim, B. 2014. Analisis multitemporal sebaran suhu permukaan laut di perairan Lombok mengunakan data penginderaan jauh modis. SIMNAS Pengindraan Jarak Jauh. hlm. 470-479.

Hanafi, A., Andriyanto, W., Syahidah, D., \& Sukresno, B. (2006). Characteristic and carrying capacity of Kaping Bay, Buleleng Regency, Bali for marine aquaculture development. Prosiding Kajian Keragaan dan Pemanfaatan Perikanan Budidaya, hlm. 83-95.

Howarth, R.W., \& Marino, R. (2006). Nitrogen as the limiting nutrient for Eutrophication in coastal marine ecosystems: Evolving views over three decades. Limnol. Oceanogr., 51(1 part 2), 164-376.

Huang, Y.C.A., Hsieh, H.J., Huang, S.C., Meng, P.J., Chen, Y.S., Keshavmurthy, S., Nozawa, Y., \& Chen, C.A. (2011). Nutrient enrichment caused by marine cage culture and its influence on subtropical coral communities in turbid waters. J. Marine Eco Progress Series., 423, 83-93. Doi: 10.3354/ meps08944.

Jayachandran, P.R., \& Nandan, S.B. (2011). Assessment of trophic change and its probable impact on tropical estuarine environment (The KodungallarAzhikode Estuary, India). Mitig Adapt Strategy Globe Change, 17, 837-847, Doi:10.1007/s11027-0119347-1.

Kamble, S.R., \& Vijay, R. (2011). Assessment of water quality using cluster analysis in coastal region of Mumbai, India. Environ. Monit. Assess., 178, 321332.

Kementerian Lingkungan Hidup [KLH]. (2004). Keputusan Menteri Negara Kependudukan dan Lingkungan Hidup No. 51 tahun 2004, tanggal 8 April 2004 tentang baku mutu air laut. Kementerian Lingkungan Hidup. Jakarta, 11 hlm.

Krivokapic, S., Pestoric, B., Bosak, S., Kuspilic, G., \& Riser, C.W. (2011). Trophic State of Boka Kotorska Bay (South-Eastern Adriatic Sea). Fresenius Envi- 
ronment Bulletin, 20(8).

Mizerkowski, D.B., Machado, E.C., Brandini, N., Nazario, M.G., \& Bonfim, K.V. (2012). Enviromental water quality assessment in Guaratuba Bay State of Parana, Southern Brazil. Brazilian Journal of Oceanography, 60(2), 109-115.

Montes, F.M.J.F., Paulo, J.G., Filho, G.A.N., Gaspar, F.L., Feitosa, F.A., Junior, A.C.S., Batista, T.N.F., Travassos, R.K., \& Pitanga, M.E. (2011). The trophic status of an urban estuarine complex in Northeast Brazil. Journal of Coastal Research, SI 64, 408-411. ICS 2011 (Proc) Poland ISSN 0749-0208.

Paerl, H.W. (2009). Controlling eutrophication along the freshwater-marine contiunum: Dual nutrient $(\mathrm{N}$ and $\mathrm{P})$ reduction are essential. Estuaries and Coasts. Doi:10.1007/s12237-009-9158-8.

Radiarta, I N., \& Erlania. (2015). Pemetaan keramba jaring apung ikan laut di Teluk Pegametan dan Teluk Penerusan, Kabupaten Buleleng, Bali. Forum Inovasi Teknologi Akuakultur (in press).

Radiarta, I N., Erlania, \& Sugama, K. (2014). Budidaya rumput laut, Kappaphycus alvarezii secara terintegrasi dengan ikan kerapu di Teluk Gerupuk Kabupaten Lombok Tengah, Nusa Tenggara Barat, J. Ris. Akuakultur, 9(1), 125-134.

Salas, F., Teixeira, H., Marcos, C., Marques, J.C., \& Perez-Ruzafa, A. (2008). Applicability of trophic index TRIX in two transitional ecosystems: the Mar Menor Lagoons (Spain) and the Mondego estuary (Portugal). J. Int. Council for the Exploration of the Sea. Oxford Journals. journal.permissions @oxfordjournals.org.

Saravi, H.N., Makhloug, A., Vahedi, F., \& Pourgholam. (2012). Eutrophication trend of caspian sea water based on absolute trophic state scale index (TRIXCS) and unscaled index (UNTRIX). The First National Conference of Phycology of Iran. Vol. 9/Special Issue/Spring 2012.

Scavia, D., \& Bricker, S.B. (2006). Coastal eutrophication assesment in United States. J. Biogeochemistry. 79, 187-208. DOI:10.1007/s10533-006-9011-0.

Seisdedo, M., Moreira, A.R., Comas, A.A., \& Arencibia, G. (2014). Analysis of tools for trophic status as- sessment of water in Cienfuegos Bay, Cuba. PanAmerican Journal of Aquatic Sciences, 9(2), 103-111.

Selman, M., Greenhalgh, S.R.D., \& Sugg, Z. (2008). Eutrophication and hipoxia in coastal areas a global assessment of the state of knowledge. WRI Policy Note, Volume 1.

Souza, M.F.L, Kjerfve, B., Knoppers, B., De Souza, W.F.L., \& Damasceno, R.N. (2003). Nutrients budgets and trophic state in a hypersaline coastal lagoon: Lagoa de Araruama, Brazil. J. Eustarine Coastal and Shelf Sicences, 57, 843-858.

Sutarmat, T., Pujiastuti, \& Perdana, N. (2014). Pendugaan limbah nutrien nitrogen dan fosfor dari aktivitas budidaya ikan dalam keramba jaring apung di Teluk Pegametan. Laporan Teknis Kegiatan Kementerian Kelautan dan Perikanan. Balai Besar Penelitian dan Pengembangan Budidaya Laut Gondol (BBRPBL-Gondol).

Taylor, D., Nixon, S., Granger, S., \& Buckley, B. (1995). Nutrient limitation and eutrophication of coastal lagoons. J. Mar. Ecol. Ser., 127, 235-244.

Tsuzuki, Y. (2006). An attempt of modification of carlson's trophic state index (TSI) for brackish lakes in Japan. J. Laguna, 13, 89-98.

Vollenwieder, R.A., Giovanardi, F., Montanari, G., \& Rinaldi, A. (1998). Characterization of the trophic state condition of marine coastal waters with special reference to The New Ardriatic Sea: J. environmentrics, 9, 329-357.

Wei, J. Zheng, H., Chen, H., Ooi, B.H., Dao, M.H., Cho, W., Malanotte-Rizzoli, P., Tkalich, P., \& Patrikalakis, N.M. (2010). Multi-layer model simulation and data assimilation in the Serangoon Harbor of Singapore. ISOPE (in press).

Weiss, R.F. (1970). Solubility of nitrogen, oxygen and argon in water and seawater. Deep-Sea Res., 17, 721-735.

Wu, M.L., Wang, Y.S., Sun, C.C., Wang, H., Dong, J.D., Yin, J.P., \& Han, S.H. (2010). Identification of coastal water quality by statistical analysis method in Daya Bay, South China Sea. J. Mar. Poll. Bull. Doi:10.1016/j.marpolbul.2010.01.007. 